\title{
Pollutants 'may harm fetal development'
}

Washington. Common environmental pollutants may be harming the development of fetuses, infants and young children by interfering with the action of key hormones, a panel of prominent scientists claimed last week. The result, they say, could be reduced levels of intelligence, and learning disorders.

The 18-member panel, which includes scientists in disciplines from toxicology to wildlife endocrinology, drew up its conclusions following a workshop on "environmental endocrine-disrupting chemicals" held last November in Erice, Sicily. They made public their concerns at a press conference in Washington.

The group claims that all pregnant women pass man-made pollutants (called endocrine disruptors) to their fetuses. As minute concentrations of hormones regulate early development, these could be seriously impeded by even trace amounts of endocrine disruptors that would not harm adults, warns the panel. "There may be no safe level of exposure," it concludes.

As evidence, the scientists cite the structural similarity of certain dioxins and polychlorinated biphenyls (PCBs) to the naturally occurring thyroid hormones that are essential in fetal development. The former have been shown experimentally to compete with thyroid hormone for binding sites on transport proteins, and to alter hormone production and metabolism. Data suggests that they sometimes mimic the hormone's action and sometimes block it. Too much or too little thyroid hormone can

\section{Health agency avoids Congress's axe}

Washington. Attempts by some Congressional Republicans to abolish the US Agency for Health Care Policy and Research (AHCPR), have been blocked in the US Senate, granting a stay of execution that may augur well for the agency's continued survival.

The \$125-million agency carries out research to improve the quality and cost-effectiveness of healthcare. But its involvement in issuing guidelines for clinical practice has made it enemies among some physicians (see Nature 377, 379; 1995).

In particular, spine and eye surgeons did not take kindly to the AHCPR's recommendations on when back or cataract surgery is warranted. They lobbied Republicans on Capitol Hill to give them the agency's head on a plate. This request that was duly met in early drafts of both Senate and House budget resolutions for 1997, which would have either eliminated or drastically reduced funding for the agency.

In a bid to forestall such drastic action, the agency told an April meeting of the House appropriations subcommittee that oversees its budget, that it would stop producing clinical guidelines. It promised to restrict its role to acting as a "science partner" with physicians and healthcare planners, conducting background research to help them develop their own guidelines.

The agency's tactics seem to have paid off. Late last month, the Senate's only physician, Bill Frist (Republican, Tennessee) took the floor to proclaim that the agency has seen the light and jettisoned its role of "telling [physicians] how to practise medicine". He added: "We should applaud this type of initiative and responsiveness, not cripple it," he said, a reference to the budget resolution which cut nearly two-thirds of the agency's budget.

Pete Domenici (Republican, New Mexico), chairman of the budget committee, promptly restored full funding for the AHCPR. The parallel House resolution, also revised from early drafts, recommends killing only the agency's clinical guidelines work, but makes no specific funding cuts. All told, the agency has survived a "close call", admits Clifton Gaus, its administrator.

But the battle is not yet over. The budget resolutions serve only as guidance for 13 appropriating subcommittees which are now drafting 1997 spending bills. Sam Johnson (Republican, Texas), the chief critic of the agency in the House, recently told the relevant subcommittee that the agency is a "boondoggle", and promised that he would "still advocate eliminating funding for the agency". But, Gaus says that he remains "optimistic" about the future of the agency.

M. W.
New Delhi. The Indian government has huge explosion and fire which occurred last week at its top missile research centre, outside Hyderabad. Sabotage is not being ruled out, given the recent terrorist bombings of a shopping centre in Delhi and a tourist bus in Rajasthan.

The Defense Research Development Organization immediately denied news reports that up to 20 people had been injured in the blast, which was heard ten $\mathrm{km}$ away. A. P. J. Abdul Kalam, the rocket designer who heads the organization, also claimed that the incident would not have any "adverse effect" on India's missile programme. But Kalam said that safety measures at the complex would be tightened, whatever the outcome of ordered a high-level investigation into a cause problems ranging from motor dysfunction to mental retardation.

"This changes things really by an order of magnitude," says Susan Porterfield, professor of physiology and endocrinology at the Medical College of Georgia, and a member of the panel. "We're talking now about the potential for very small quantities of these compounds having very significant effects," she says, pointing out that the toxicity of other environmental pollutants is proportional to their concentration.

The scientists concede that knowledge of these and other pollutant hormone interactions is still incomplete. But they claim that this example is only the tip of a dangerous iceberg, and that many substances - some unidentified - may also interfere with early development of the brain and nervous system. "It is imperative to monitor levels of contaminants in humans, animals and the environment," the panel concludes.

Endocrine disruptors occur in everything from plasticizers to pesticides, according to the panel. Yet government spending on monitoring them is "trivial". Moreover, the scientists say, the interdisciplinary research needed to increase understanding of the pollutants' effects suffers because of the "narrow expertise" of grant-making scientific panels.

The panel recommends that manufacturers be obliged to name all the chemicals in their products and assure that these pose no developmental health hazards. But this is rejected as unrealistic by Jon Holtzman, a spokesman for the Chemical Manufacturers Association, who argues that it would require companies to divulge proprietary information. US companies already "abide by the most rigorous reporting system in the world", he says.

Meredith Wadman

\section{India's missile centre shaken by blast}

the enquiry into the explosion.

The damage, described as "heavy", was confined to the laboratory for developing chemical additives for propellants in the High Energy Materials building where the explosion occurred, according to Kalam. "The main laboratory a few metres away, where missiles are assembled, escaped unscathed," he said.

The research centre is central to India's plans to develop medium and long-range missiles, including the surface-to-surface Prithvi missile. The programme is controversial, anti-nuclear organizations arguing that the missiles could be fitted with the nuclear warheads that India is believed to have developed following its underground nuclear test in 1974 . K. S. Jayaraman 